\title{
Phytochemical and antibacterial activity of Mangifera indica Linn (Mango) bark and leaf extracts on bacteria isolated from domestic wastewater samples
}

\author{
${ }^{1}$ Omotayo, O. E., ${ }^{2}$ Oladipo, G. A., ${ }^{3}$ Adekunle, D. O., and ${ }^{2}$ Akinola, O. T. \\ ${ }^{1}$ Pure and Applied Biology Programme, College of Agriculture, Engineering and Science, \\ P. M. B 284, Iwo, Osun State, Nigeria \\ ${ }^{2}$ Microbiology Programme, College of Agriculture, Engineering and Science, P.M.B 284, Iwo, Osun State, Nigeria \\ ${ }^{3}$ Industrial Chemistry Programme, College of Agriculture, Engineering and Science, \\ P. M. B 284, Iwo, Osun State, Nigeria \\ *Correspondence to: olumide.omotayo@bowen.edu.ng; +234 8023799838
}

\begin{abstract}
:
Background: Wastewaters generated from ubiquitous use of water in daily human activities often contains various pathogenic microorganisms, which may contaminate surface or ground waters when released indiscriminately into the environment. Consumption of natural water resources polluted by such contaminated wastewaters may compromise public health and decrease the populations of aquatic organisms in such water bodies. Mangifera indica (mango) plants have been widely used as remedy for treatment of a wide range of water borne ailments. This study was therefore conducted to identify bacteria contaminating wastewaters from domestic sources and to determine the antibacterial potentials of mango bark and leaf extracts against them.

Methodology: Wastewater samples were obtained from the wash areas of five randomly selected female hostels in Bowen University, Iwo, Osun State, Nigeria. Bacteria in the wastewater samples were isolated by standard aerobic cultures and identified using conventional biochemical test schemes. The antimicrobial activities of the methanol extracts of $M$. indica leaf and bark, and a standard antibiotic (tetracycline), were determined by the modified disc diffusion test. Phytochemical analysis of the extracts was determined by standard method, and the active compounds in them were analyzed by FT-IR spectroscopy using Agilent technologies FT-IR spectrometer at a scan range of $4,000-600 \mathrm{~cm}^{-1}$.

Results: The bacterial species isolated from the wastewater samples included Escherichia coli, Proteus mirabilis, Salmonella spp, Pseudomonas aeruginosa and Klebsiella pneumoniae, with E. coli the most frequent (35.7\%) and $K$. pneumoniae the least frequent $(7.1 \%)$. Leaf extract $(30 \mu \mathrm{g})$ of $M$. indica exerted high antimicrobial activity against Salmonella spp (inhibition zone diameter of $15 \mathrm{~mm}$ ) while the bark extract exerted high antimicrobial activity against $P$. aeruginosa (inhibition zone diameter of $13 \mathrm{~mm}$ ). Comparatively, tetracycline ( $30 \mu \mathrm{g}$ ) exerted highest antimicrobial activity against Salmonella spp (inhibition zone diameter of $18 \mathrm{~mm}$ ) but no activity against $P$. aeruginosa (inhibition zone diameter of $0 \mathrm{~mm}$ ). The FT-IR analysis confirmed the presence of several functional groups with antimicrobial potentials such as flavonoids, alkaloids, tannins, saponins, phenols, and phytosterols.

Conclusion: These results indicate the antibacterial potential effects of $M$. indica leaf and stem bark extracts against some bacterial isolates, and thus may be recommended for biological treatment of water contaminated by wastewater sources.
\end{abstract}

Keywords: antimicrobial; phytochemical; bioactivity; Mangifera indica; bacteria; wastewater

Received Jul 3, 2021; Revised Oct 8, 2021; Accepted Oct 11, 2021; Published online Jan 18, 2022

Copyright 2022 AJCEM Open Access. This article is licensed and distributed under the terms of the Creative Commons Attrition 4.0 International License $<$ rel="license" href="http://creativecommons.org/licenses/by/4.0/", which permits unrestricted use, distribution and reproduction in any medium, provided credit is given to the original author(s) and the source. Editor-in-Chief: Prof. S. S. Taiwo

\section{Activité phytochimique et antibactérienne d'extraits d'écorce et de feuilles de Mangifera indica Linn (Mangue) sur des bactéries isolées d'échantillons d'eaux usées domestiques}

\author{
${ }^{1}$ Omotayo, O. E., ${ }^{2}$ Oladipo, G. A., ${ }^{3}$ Adekunle, D. O., et ${ }^{2}$ Akinola, O. T.
}


${ }^{1}$ Programme de biologie pure et appliquée, Collège d'agriculture, d'ingénierie et des sciences,

P. M. B 284, Iwo, État d'Osun, Nigéria

${ }^{2}$ Programme de microbiologie, Collège d'agriculture, d'ingénierie et des sciences, P.M.B 284, Iwo, État d'Osun, Nigéria

${ }^{3}$ Programme de chimie industrielle, Collège d'agriculture, d'ingénierie et des sciences, P. M. B 284, Iwo, État d'Osun, Nigéria

*Correspondance à: olumide.omotayo@bowen.edu.ng; +234 8023799838

\section{Résumé:}

Contexte: Les eaux usées générées par l'utilisation omniprésente de l'eau dans les activités humaines quotidiennes contiennent souvent divers micro-organismes pathogènes, qui peuvent contaminer les eaux de surface ou souterraines lorsqu'ils sont rejetés sans discernement dans l'environnement. La consommation de ressources en eau naturelles polluées par de telles eaux usées contaminées peut compromettre la santé publique et diminuer les populations d'organismes aquatiques dans ces plans d'eau. Les plantes Mangifera indica (mangue) ont été largement utilisées comme remède pour le traitement d'un large éventail de maladies d'origine hydrique. Cette étude a donc été menée pour identifier les bactéries contaminant les eaux usées d'origine domestique et pour déterminer les potentiels antibactériens de l'écorce et des extraits de feuilles de manguier contre elles.

Méthodologie: Des échantillons d'eaux usées ont été prélevés dans les zones de lavage de cinq foyers pour femmes sélectionnés au hasard à l'Université Bowen, Iwo, État d'Osun, Nigéria. Les bactéries présentes dans les échantillons d'eaux usées ont été isolées par des cultures aérobies standard et identifiées à l'aide de schémas de tests biochimiques conventionnels. Les activités antimicrobiennes des extraits au méthanol des feuilles et de l'écorce de $M$. indica et d'un antibiotique standard (tétracycline) ont été déterminées par le test de diffusion sur disque modifié. L'analyse phytochimique des extraits a été déterminée par une méthode standard, et les composés actifs qu'ils contiennent ont été analysés par spectroscopie FT-IR à l'aide du spectromètre FTIR Agilent technologies à une plage de balayage comprise entre 4000-600 $\mathrm{cm}^{-1}$.

Résultats: Les espèces bactériennes isolées des échantillons d'eaux usées comprenaient Escherichia coli, Proteus mirabilis, Salmonella spp, Pseudomonas aeruginosa et Klebsiella pneumoniae, avec E. coli le plus fréquent (35,7\%) et $K$. pneumoniae le moins fréquent $(7,1 \%)$. L'extrait de feuille $(30 \mu g)$ de $M$. indica a exercé une activité antimicrobienne élevée contre Salmonella spp (diamètre de la zone d'inhibition de $15 \mathrm{~mm}$ ) tandis que l'extrait d'écorce a exercé une activité antimicrobienne élevée contre $P$. aeruginosa (diamètre de la zone d'inhibition de $13 \mathrm{~mm})$. En comparaison, la tétracycline $(30 \mu \mathrm{g})$ a exercé la plus forte activité antimicrobienne contre Salmonella spp (diamètre de la zone d'inhibition de $18 \mathrm{~mm}$ ) mais aucune activité contre $P$. aeruginosa (diamètre de la zone d'inhibition de $0 \mathrm{~mm}$ ). L'analyse FT-IR a confirmé la présence de plusieurs groupes fonctionnels à potentiel antimicrobien tels que les flavonoïdes, les alcaloïdes, les tanins, les saponines, les phénols et les phytostérols. Conclusion: Ces résultats indiquent les effets potentiels antibactériens des extraits de feuilles et d'écorce de tige de $M$. indica contre certains isolats bactériens, et peuvent donc être recommandés pour le traitement biologique de l'eau contaminée par des sources d'eaux usées.

Mots-clés: antimicrobien; phytochimique; bioactivité; Mangifera indica; bactéries; les eaux usées

\section{Introduction:}

The common saying goes 'water is life'. This same indispensable element that has been recognized as a source of life may also well be termed a source of sickness and death, especially in developing countries such as Nigeria. Water sources may become easily contaminated and polluted due to their adoption for ubiquitous purposes especially in rural and semi-urban settings, where adequate treatment facilities and/or chemicals may not be readily available, accessible, or functional. It is an indisputable fact that water is essential to the major life processes of plants and animals. Its occurrence and utilization in a vast array of biological processes such as photo synthesis, transpiration, excretion, growth, reproduction, and so on underscores the crucial importance of this element. An adequate, safe, and accessible supply must therefore be available to all. Improving access to safe drinking water and other purposes like domestic, indus- trial and agricultural purposes can result in significant benefits to public health.

The major microorganisms in wastewater effluents are viruses, bacteria, fungi, pro tozoans and helminthes (1). Water-borne infections may have serious consequence for the immunologically compromised individuals (2). Bacteria in wastewaters are usually from faecal droplets of individuals with acute disease or carriers, which can be pathogenic with capacity to cause infection and allergies, and can easily contaminate and disseminate in the soil. The possibility of contamination of underground water sources from indiscriminate release of wastewater is a very grim reality in developing countries and this in turn, may have grave impact on the public health status of the populace who are highly dependent on these water sources to meet their daily domestic needs.

The use of plant extracts has long been exploited in folk medicine for therapeutic antimicrobial and antioxidant properties. Natural 
bioactive compounds have also been found to interfere with development of cancers (3). On the other hand, the efficacy of synthetic antimicrobial agents has been mitigated due to the continuing emergence of drug resistant microorganisms and the adaptations by microbial pathogens to commonly used antimicrobials (4). This therefore necessitates the continuous exploration of local plant resources that may be exploited to address the health and environmental challenges where such plant resources exist.

Mangifera indica (Mango) is a fruit crop which is the most widely cultivated and economically important species of the family Anacardiaceae, a family of many tropical species (5). The phytotherapeutic effects of Mango plant parts have been well documented. Abdul et al., (6) reported that leaf extracts of $M$. indica demonstrated notable inhibitory effects on antibiotic sensitive and multi-drug resistant Salmonella Typhi. Disegha and Akani (7) also reported that $M$. indica extracts were effective as anti-fungal agents in the treatment of infectious diseases caused by Candida albicans and Aspergillus spp. Mango plant parts have traditionally been widely used as herbal remedy for a wide range of ailments due to their association with many pharmacological effects (8).

Fourier-transform infrared (FT-IR) spectroscopy is a high-resolution analytical tool used to identify the chemical constituents of compounds and elucidate structural components (3). This study was conducted using FTIR spectroscopy to screen for the functional groups of extracts of the leaf and bark of $M$. indica. In addition, the antibacterial activities of the phytochemical components of this plant were tested on bacteria isolated from wastewaters.

\section{Materials and method:}

\section{Collection and preparation of plant materials}

Fresh leaves and barks of $M$. indica (Mango) were collected from tree stands located within Bowen University campus, Iwo, Nigeria, and identified at the herbarium of the Department of Botany, University of Ibadan, Ibadan, Nigeria. The plant samples were airdried at room temperature for 10 days to remove the residual moisture. The dried leaves were then ground to powder using an electrical blender while the bark portions were first pulverized in a mortar before using a mechanical grinder. The pulverized plant material was then stored in sterile air-tight containers before use.

\section{Extraction of mango leaf and bark for phyto- chemical screening}

Methanol, ethanol, hexane and distilled water were selected for extracting the plant materials for phytochemical screening. The coarse powder $(100 \mathrm{~g})$ was soaked in $250 \mathrm{ml}$ of each solvent for 48 hours and filtered using Whatman No. 1 filter papers. Soxhlet apparatus was used to obtain crude extracts from the solvent by evaporating the extracts to dried form. Pulverized samples of leaf and bark were extracted using methanol at room temperature using the cold maceration method by soaking $100 \mathrm{~g}$ of each sample in $500 \mathrm{ml}$ of methanol for 48 hours. Each extract sample was evaporated using a rotatory evaporator with Stuart digital water bath (RE300DB) at $45^{\circ} \mathrm{C}$ under reduced pressure. Phytochemical constituents were screened for tannins, alkaloids, saponins, glycosides, flavonoids, phenols, protein and phytoesterols according to the method described by Prabhavathi et al., (9).

\section{FT-IR spectrum analysis}

The extracts of $M$. indica stem bark and leaf were loaded onto FT-IR spectroscope and the spectroscopy results were recorded on an Agilent Technology FT-IR spectrometer (Cary 630 ) at a scan range between 4,000-600 $\mathrm{cm}^{-1}$.

\section{Collection of wastewater samples}

Wastewater samples were collected into sterile sample bottles from the wash areas of five randomly selected ladies' hostels (UPE, SADLER, NH1, NH2 and NH3) in Bowen University (BU), Iwo, Nigeria. They were then placed aseptically inside new polythene bags and transported to the microbiology laboratory of the University for analyses.

\section{Physico-chemical analysis of the wastewater samples}

The $\mathrm{pH}$ of the wastewater samples was tested using the Test 2 waterproof digital $\mathrm{pH}$ meter. Prior to measurement, standard calibration procedure was done for the $\mathrm{pH}$ meter using standard buffer solutions. Turbidimetric method (10) was used to determine the sulphate $\left(\mathrm{SO}_{4}{ }^{2-}\right)$ content, and acid colorimetric method was used to determine the phosphate $\left(\mathrm{PO}_{4}{ }^{3-}\right)$ anions level in the wastewater samples.

\section{Isolation of bacteria}

Bacteria were isolated from the wastewater samples using the ten-fold serial dilution method (11). Different dilutions were plated onto Petri dishes containing sterilized nutrient agar (Lab M) until pure cultures were obtained. 
Pure cultures of the bacterial isolates were identified based on their colony morphology, Gram stain reaction, and conventional biochemical tests such as citrate utilization, indole, sugar fermentation, starch hydrolysis, methyl red and Voges-Proskauer tests, in accordance with the Bergey's manual of systematic bacteriology (12).

\section{Test bacteria for antimicrobial assay}

Pure cultures of the following bacteria were selected for antimicrobial assay; Staphylococcus aureus, Klebsiella pneumoniae, Pseudomonas aeruginosa, Escherichia coli, Salmonella sp., and Proteus mirabilis. Biochemical tests were used to confirm the identity of the isolates according to the method described by Cheesbrough (13). The organisms were subcultured on nutrient agar (NA) plates and then stored on nutrient agar slants at $4^{\circ} \mathrm{C}$ until use.

\section{Antimicrobial assay}

The modified agar disc diffusion of Bauer et al., (14) was used for antimicrobial assay. Whatman No. 1 filter paper was cut using a paper perforator into discs measuring 4 $\mathrm{mm}$ in diameter and sterilized in an autoclave. A stock solution of the Mango extracts was prepared by dissolving $100 \mathrm{mg}$ of each extract in $1 \mathrm{ml}$ of methanol and kept in the fridge until use. The stock solution was diluted $(x 100)$ at the point of working to obtain the working solution using the formula $\mathrm{C}_{1} \mathrm{~V}_{1}=\mathrm{C}_{2} \mathrm{~V}_{2}$, where $\mathrm{C}_{1}=$ concentration of stock solution, $\mathrm{V}_{1}=$ volume of stock solution, $\mathrm{C}_{2}=$ concentration of working solution and $\mathrm{V}_{2}=$ volume of working solution. From the working solution, a fixed volume of $0.03 \mathrm{ml}$ (equivalent to $0.03 \mathrm{mg}$ or $30 \mu \mathrm{g}$ ) of each extract was carefully used to load (impregnate) each disc and the impregnated discs were placed in Petri dishes approximately $5 \mathrm{~mm}$ apart, taking precautions that the tip was in slight contact with the sterilized disc using a micro pipette. All impregnated discs were fully dried in a container.

Mueller Hinton agar (Lab M) was prepared under standard conditions. Inoculum of pure cultures of each bacteria isolate was prepared and standardized by adjusting its turbidity to match 0.5 McFarland standard, giving inoculum size of approximately $1 \times 10^{8} \mathrm{CFU} / \mathrm{ml}$.
The plates were streak-inoculated with a sterile swab stick dipped into the inoculum. The prepared discs were applied with a sterile forcep onto the surface of the seeded agar plates, along with standard tetracycline $(30 \mu \mathrm{g})$ disc as comparative control. The plates were incubated aerobically for 48 hours at $37^{\circ} \mathrm{C}$. Antimicrobial activity was determined by measuring the diameter (in millimetres) of the zone of inhibition with a calibrated ruler. The antimicrobial assay for the extracts and tetracycline control was carried out in duplicate, and the average of the two replicated results was calculated for each isolate.

\section{Results:}

Five bacteria isolates were obtained from the wastewater samples. Fig. 1 shows the relative frequency of occurrence of the bacteria isolates from the wastewater samples. All isolated bacteria were Gram-negative rods and identified as Escherichia coli, Proteus mirabilis, Salmonella sp., Pseudomonas aeruginosa and Klebsiella pneumoniae. The results obtained from the physico-chemical test carried out on the water samples are shown on Table 1.

Table 1: Physico-chemical parameters of wastewater samples

\begin{tabular}{llll}
\hline Parameters & pH & $\begin{array}{l}\text { PO }_{4}{ }^{3-} \text { conc. } \\
\mathbf{W L ~ 4 7 0 ~} \mathbf{~ n m}\end{array}$ & $\begin{array}{l}\text { SO }_{4}{ }^{2-} \text { conc } \\
\mathbf{W L ~ 4 2 5} \mathbf{~ n m}\end{array}$ \\
Sample A (UPE) & 7.0 & -0.062 & 0.553 \\
Sample B (SADLER) & 6.5 & 0.114 & 1.225 \\
Sample C (NH1) & 7.3 & -0.060 & 0.583 \\
Sample D (NH2) & 7.5 & 0.270 & 0.249 \\
Sample E (NH3) & 8.0 & 0.040 & 0.730 \\
\hline $\mathrm{PO}_{4}{ }^{3-}=$ Phosphate concentration; $\mathrm{SO}_{4}{ }^{2-}=$ Sulphate concentration; WL=Wavelength
\end{tabular}

The $\mathrm{pH}$ values of the wastewater samples ranged from 6.5-8.0. Wastewater from hostel NH2 (sample D) had the highest phosphate concentration (0.270) while wastewater from UPE hostel (sample $A$ ) had the lowest concentration $(-0.062)$, and wastewater from $\mathrm{NH} 1$ hostel (sample $\mathrm{C}$ ) had the lowest BOD level of $110 \mathrm{mg} / \mathrm{L}$. The results of sulphate concentration test showed that wastewater sample from SADLER hostel (sample B) had the highest concentration (1.225) while wastewater from $\mathrm{NH} 2$ hostel (sample D) had the lowest concentration (0.249). 


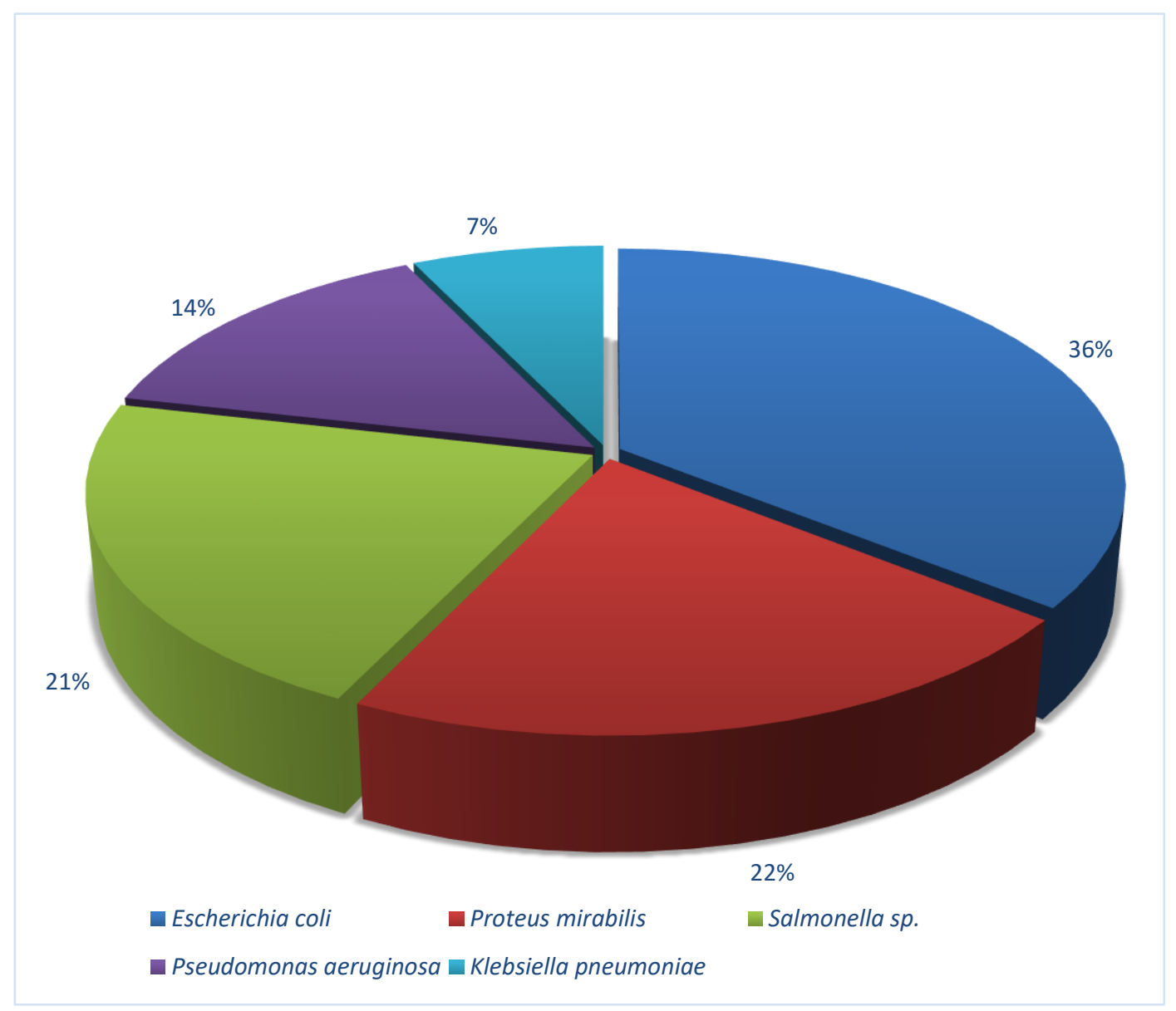

Fig. 1: Frequency of isolation of bacteria from wastewater samples

Table 2: Phytochemical composition of Mangifera indica leaves and stem barks

\begin{tabular}{|c|c|c|c|c|c|c|c|c|c|c|c|c|}
\hline \multirow[t]{2}{*}{ Test } & \multirow{2}{*}{$\begin{array}{l}\text { Reagent } \\
\text { used }\end{array}$} & \multirow[t]{2}{*}{ Observation } & \multicolumn{5}{|c|}{ Leaf extract } & \multicolumn{5}{|c|}{ Stem bark extract } \\
\hline & & & Ls & Aq. & Eth & Meth & Hex & Bs & Aq. & Eth & Meth & Hex \\
\hline Tannins & $\mathrm{FeCl}_{3}$ & $\begin{array}{l}\text { Blue black } \\
\text { coloration }\end{array}$ & + & + & + & + & + & + & + & + & + & + \\
\hline Alkaloids & $\begin{array}{l}\text { Marquis } \\
\text { reagent }\end{array}$ & $\begin{array}{c}\text { Dark orange or } \\
\text { purple }\end{array}$ & + & + & + & + & + & + & + & + & + & + \\
\hline Saponins & $\begin{array}{l}\text { Distilled } \\
\text { water }\end{array}$ & Stable foams & + & + & + & + & + & + & + & + & + & + \\
\hline $\begin{array}{l}\text { Cardiac } \\
\text { glycosides }\end{array}$ & $\begin{array}{c}\text { Glacial } \\
\text { acetic acid } \\
\text { and } \mathrm{FeCl}_{3}\end{array}$ & $\begin{array}{l}\text { Brownish green } \\
\text { ring }\end{array}$ & + & + & + & + & + & + & + & + & + & + \\
\hline Flavonoids & $\begin{array}{l}\mathrm{NH}_{3}+ \\
\mathrm{H}_{2} \mathrm{SO}_{4}\end{array}$ & Yellow coloration & + & - & + & + & + & + & - & - & - & + \\
\hline Phenols & $\begin{array}{l}\text { Aqueous } \\
\mathrm{FeCl}_{3}\end{array}$ & Blue coloration & - & - & + & - & + & - & - & + & - & + \\
\hline Protein & $\begin{array}{c}\text { Conc. } \\
\text { nitric acid }\end{array}$ & Yellow coloration & - & - & - & - & + & - & - & - & - & + \\
\hline Phytosterol & $\begin{array}{c}\text { Acetic } \\
\text { anhydride } \\
+\mathrm{H}_{2} \mathrm{SO}_{4}\end{array}$ & Brown ring & + & + & + & + & + & + & + & + & + & + \\
\hline
\end{tabular}


The results for qualitative phytochemical screening of $M$. indica leaf and bark are presented on Table 2. Alkaloids, saponins, tannins, phytoesterols and glycosides were present in all the methanolic, aqueous, ethanol and hexane leaf and bark extracts. Protein was present in the hexane extract but absent in aqueous, ethanol and methanol extracts of both leaf and bark samples. Flavonoids were present in the ethanolic, methanolic and hexane extracts of the leaf, but absent in the aqueous, ethanol and methanol extracts of the bark. Phenol was present in both the ethanol and hexane extracts of the leaf and bark, but absent in the aqueous and methanolic extracts of the plant samples.

The spectrum of $M$. indica was recorded in wavelength $4000-600 \mathrm{~cm}^{-1}$. The result of the FT-IR analysis confirmed the presence of functional groups such as $\mathrm{O}-\mathrm{H}, \mathrm{C}=\mathrm{C}, \mathrm{C}-\mathrm{H}, \mathrm{C}-\mathrm{O}$ and $\mathrm{CH}_{3}$ (Tables 3 and 4). The highest (strong instance) peak appears at a wavelength of $3321.1 \mathrm{~cm}^{-1}$ and a transmittance of $63.892 \%$, which indicates the presence of $\mathrm{O}-\mathrm{H}$ stretching and $\mathrm{H}$-bonded of alcohols and phenols.

Table 3: FT-IR interpretation of compounds of methanol leaf extract of Mangifera indica

\begin{tabular}{|c|c|c|c|}
\hline $\begin{array}{l}\text { Wavenumber } \text { cm }^{-1} \\
\text { (Test Sample) }\end{array}$ & \% Transmittance & $\begin{array}{c}\text { Functional Group } \\
\text { assignment }\end{array}$ & $\begin{array}{c}\text { Expected Phyto } \\
\text { compounds identified }\end{array}$ \\
\hline 3321.1 & 63.892 & $\begin{array}{l}\mathrm{H}-\text { bonded, } \mathrm{O}-\mathrm{H} \\
\text { stretch }\end{array}$ & $\begin{array}{l}\text { Hydroxyl compound, } \\
\text { alcohols, phenols }\end{array}$ \\
\hline 2942.7 & 74.583 & $\begin{array}{l}\text { Asymmetric } \\
\text { stretching of }-\mathrm{CH} \\
\left(\mathrm{CH}_{2}\right) \text { vibration }\end{array}$ & $\begin{array}{l}\text { Saturated aliphatic } \\
\text { compounds }\end{array}$ \\
\hline 2834.6 & 77.550 & $\begin{array}{l}\text { Symmetric } \\
\text { stretching of }-\mathrm{CH} \\
\left(\mathrm{CH}_{2}\right) \text { vibration }\end{array}$ & $\begin{array}{l}\text { Fatty acids, lipids, } \\
\text { protein }\end{array}$ \\
\hline 1612.1 & 84.397 & $\mathrm{C}=\mathrm{O}$ stretching & Carbonyl compound \\
\hline 1448.1 & 76.760 & $\begin{array}{c}\mathrm{C}=\mathrm{C}-\mathrm{C} \text {, aromatic } \\
\text { ring }\end{array}$ & Aromatic compound \\
\hline 1110.7 & 79.321 & $\begin{array}{l}\mathrm{O}-\mathrm{H} \text { bend, alcoholic } \\
\text { group }\end{array}$ & Phenol, tertiary alcohol \\
\hline 1017.6 & 24.291 & $\mathrm{PO}_{3}$ stretch & Phosphate ion \\
\hline
\end{tabular}

Table 4: FT-IR Interpretation of compounds of methanol stem bark extract of Mangifera indica

\begin{tabular}{|c|c|c|c|}
\hline $\begin{array}{c}\text { Wavenumber } \mathrm{cm}^{-1} \\
\text { (Test Sample) }\end{array}$ & $\%$ Transmittance & $\begin{array}{c}\text { Functional Group } \\
\text { assignment }\end{array}$ & $\begin{array}{c}\text { Expected Phyto } \\
\text { compounds identified }\end{array}$ \\
\hline 3304.3 & 64.450 & $\begin{array}{l}\mathrm{H}-\text { bonded, } \mathrm{O}-\mathrm{H} \\
\text { stretch }\end{array}$ & $\begin{array}{l}\text { Hydroxyl compound, } \\
\text { alcohols, phenols }\end{array}$ \\
\hline 2946.5 & 76.168 & $\begin{array}{l}\text { Asymmetric } \\
\text { stretching of }-\mathrm{CH} \\
\left(\mathrm{CH}_{2}\right) \text { vibration }\end{array}$ & $\begin{array}{l}\text { Saturated aliphatic } \\
\text { compounds }\end{array}$ \\
\hline 2834.6 & 79.684 & $\begin{array}{l}\text { Symmetric } \\
\text { stretching of }-\mathrm{CH} \\
\left(\mathrm{CH}_{2}\right) \text { vibration }\end{array}$ & $\begin{array}{l}\text { Fatty acids, lipids, } \\
\text { protein }\end{array}$ \\
\hline 1619.5 & 84.578 & $\mathrm{C}=\mathrm{O}$ stretching & Carbonyl compound \\
\hline 1488.1 & 78.893 & $\begin{array}{c}\mathrm{C}=\mathrm{C}-\mathrm{C} \text {, aromatic } \\
\text { ring }\end{array}$ & Aromatic compound \\
\hline 1112.6 & 80.859 & $\begin{array}{c}\mathrm{O}-\mathrm{H} \text { bend, alcoholic } \\
\text { group }\end{array}$ & Phenol, tertiary alcohol \\
\hline 1015.7 & 28.059 & $\mathrm{PO}_{3}$ stretch & Phosphate ion \\
\hline
\end{tabular}


Fig 2 shows the combined FI-TR spectra of $M$. indica leaf and bark extracts. In Fig 3, the FT-IR spectra peak at $3,321.1 \mathrm{~cm}^{-1}$ for $M$. indica stem bark extract revealed the presence of alcohols and phenols $(\mathrm{O}-\mathrm{H}$ stretch, $\mathrm{H}$-bonded), the peaks at 2942.7 and 2834.6 $\mathrm{cm}^{-1}$ showed the presence of alkanes $(\mathrm{C}-\mathrm{H}$ stretch), the peak at $1619.5 \mathrm{~cm}^{-1}$ revealed the presence of carboxylic acid group $(\mathrm{C}=\mathrm{O}$ stretch), the peak at $1488.1 \mathrm{~cm}^{-1}$ showed the presence of aromatic compounds (C-N stretch), and the peaks at 1112.6 and $1015.7 \mathrm{~cm}^{-1}$ indicate presence of alcohols, esters, ethers, and phosphate (O-H bend).

Fig 4 shows the FT-IR spectra of $M$. indica leaf extracts, with the peaks at 3,304.3, $2946.5,2834.6,1619.5,1488.1,1112.6$ and $1015.7 \mathrm{~cm}^{-1}$ revealing the presence of alcohols, ( $\mathrm{O}-\mathrm{H}$ stretch, $\mathrm{H}$-bonded), fatty acids and lipids ( $\mathrm{H}-\mathrm{C}=\mathrm{O}, \mathrm{C}-\mathrm{H}$ stretch), nitriles ( $\mathrm{C}=\mathrm{O}$ stretch), carbonyls $(\mathrm{C}=\mathrm{O}$ stretch), aromatics $(\mathrm{C}=\mathrm{C}-\mathrm{C})$, phenols $(\mathrm{O}-\mathrm{H}$ bend $)$, and phosphate $(\mathrm{O}-\mathrm{H}$ bend).

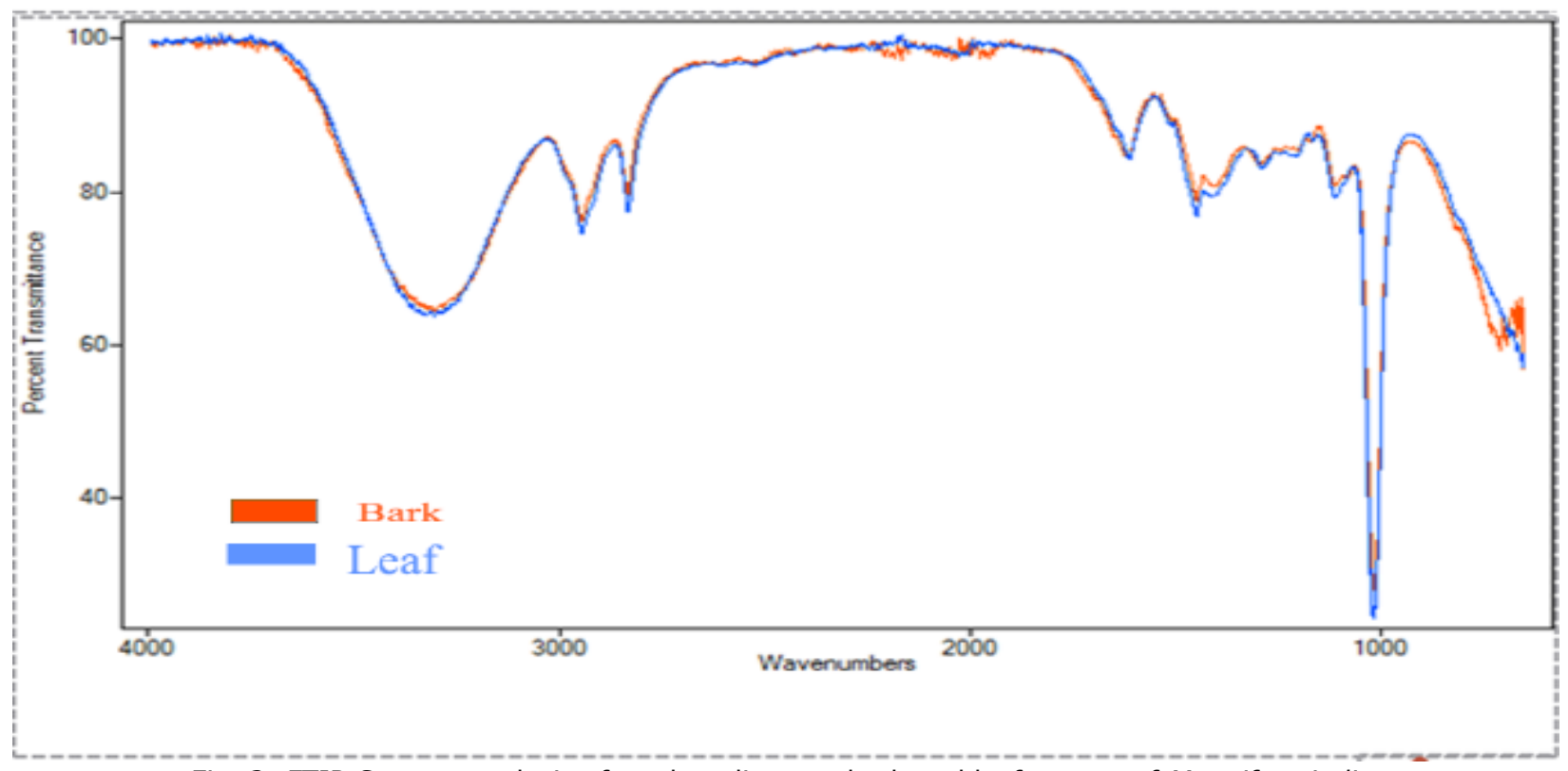

Fig. 2: FTIR Spectra analysis of methanolic stem bark and leaf extract of Mangifera indica

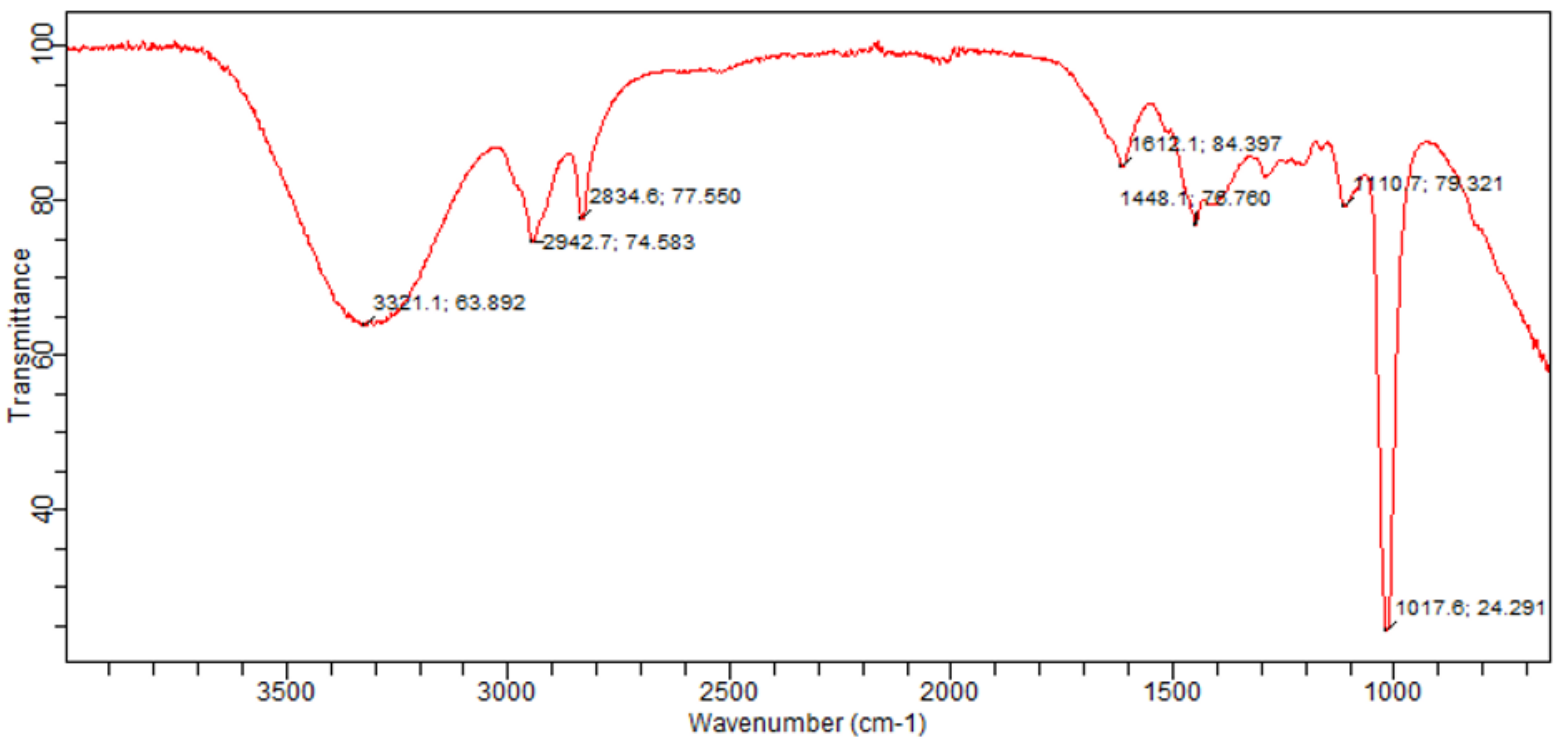

Fig. 3: FTIR spectrum analysis of methanol stem bark extract of Mangifera indica 


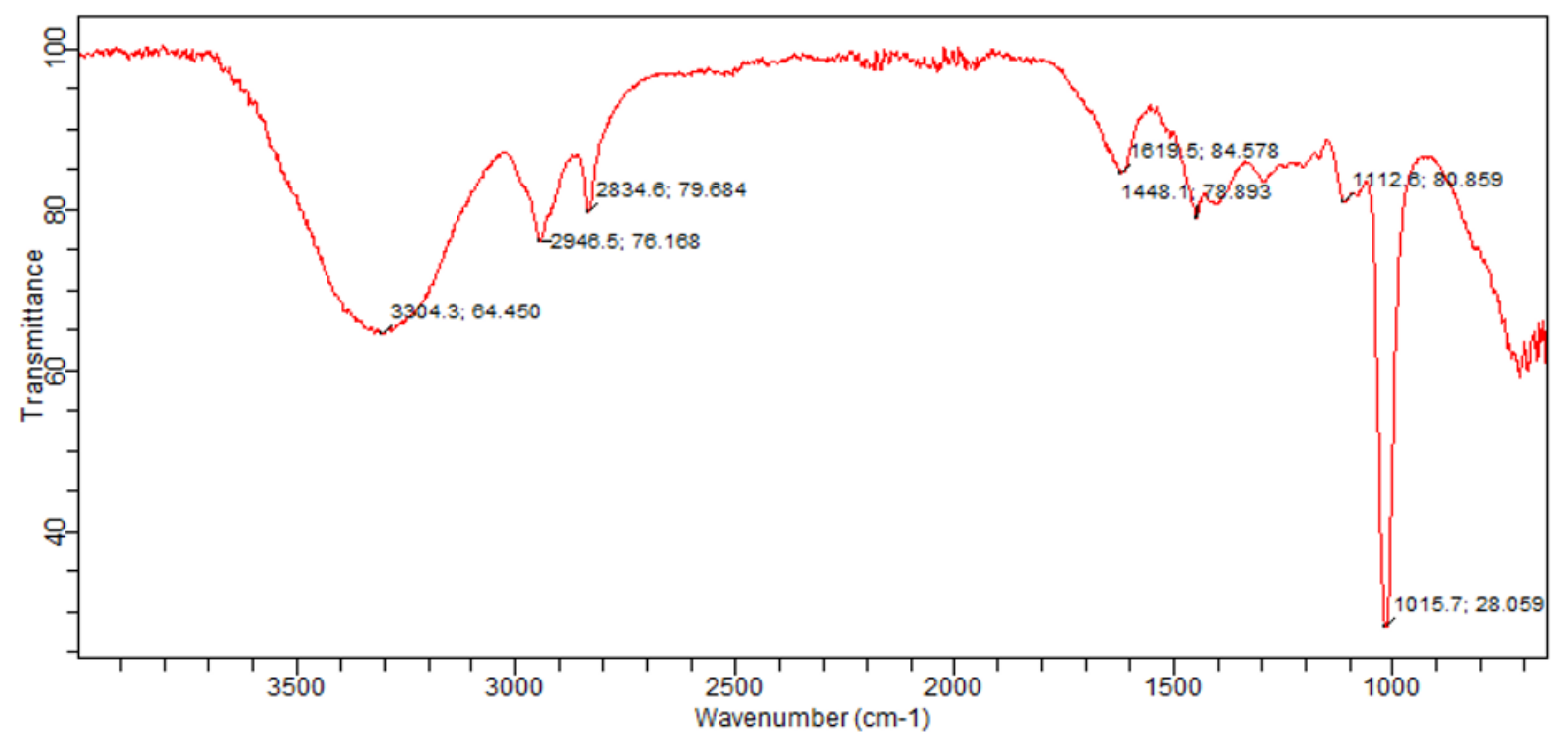

Fig. 4: FT-IR spectrum analysis of methanol leaf extract of Mangifera indica

Table 5: Antibacterial activity of methanolic extracts of Mangifera indica on selected bacterial isolates

\begin{tabular}{cccc}
\cline { 2 - 4 } Bacteria isolate & \multicolumn{3}{c}{ Zone diameter of inhibition $(\mathbf{m m})$} \\
\cline { 2 - 4 } & Mango leaf $(30 \mu \mathrm{g})$ & Mango bark $(30 \mu \mathrm{g})$ & Tetracycline $(30 \mu \mathrm{g})$ \\
\hline Pseudomonas aeruginosa & 12.5 & 13 & 0 \\
Staphylococcus aureus & 8.5 & 0 & 13.5 \\
Klebsiella pneumoniae & 10.5 & 0 & 18 \\
Salmonella spp & 15 & 12 & 13 \\
Escherichia coli & 11 & 8 & 10 \\
Proteus mirabilis & 10 & 0 & \\
\hline
\end{tabular}

The result of the antimicrobial assay in Table 5 shows the diameters of inhibition zone (in millimetres) of the isolates to the plant extracts. Leaf extracts of $M$. indica $(30 \mu \mathrm{g})$ exerted highest antimicrobial activity against Salmonella spp (inhibition zone diameter of 15 $\mathrm{mm}$ ) and $P$. aeruginosa (inhibition zone diameter of $12.5 \mathrm{~mm}$ ), and least activity against $S$. aureus (inhibition zone diameter of $8.5 \mathrm{~mm}$ ).

The extract of $M$. indica bark $(30 \mu \mathrm{g})$ exerted highest antimicrobial activity against $P$. aeruginosa (inhibition zone diameter of $13 \mathrm{~mm}$ ) and Salmonella spp (inhibition zone diameter of $12 \mathrm{~mm}$ ) and no activity against $S$. aureus, $K$. pneumoniae and $P$. mirabilis (inhibition zone diameter of $0 \mathrm{~mm}$ each). Comparatively, tetracycline $(30 \mu \mathrm{g})$ exerted highest antimicrobial activity against Salmonella spp (inhibition zone diameter of $18 \mathrm{~mm}$ ) but no activity against $P$. aeruginosa (inhibition zone diameter of $0 \mathrm{~mm}$ ).

\section{Discussion:}

Water is such a common everyday substance that its significance in biological systems may tend to be underestimated. Various microorganisms may be commonly found in wastewater, many of which are pathogenic. Gram negative bacteria belonging to five genera were isolated from the wastewater samples; E. coli, Proteus mirabilis, Salmonella spp, $P$. aeruginosa and $K$. pneumoniae. These Gram-negative bacteria are usually implicated in a number of important water-borne diseases and thus their presence in the sampled wastewater indicates such water requires adequate treatment before discharge into the environment, particularly through run-off into surface water bodies. In a similar study (15) evaluating presence of pathogenic organisms in wastewater samples, bacteria such as $P$. aeruginosa, K. pneumoniae, 
E. coli, Bacillus cereus and Streptococcus pneumoniae were isolated from wastewater. Ghai et al., (16) also isolated E. coli, B. cereus, Enterobacter sp. and $S$. aureus from standing pond water, with the highest frequency of occurrence of $E$. coli $(36 \%)$ with $K$. pneumoniae the least frequency of occurrence $(7 \%)$. This indicates that faecal matters may be a major pollutant of the wastewater being generated from the point sources of their collection. In another study by Shivani et al., (17), Bacillus spp had the highest frequency of occurrence (38.86\%) while $P$. aeruginosa had the lowest frequency $(7.69 \%)$. Though these organisms are opportunistic pathogens, their presence in these wastewater samples could prove lethal when such waters find their way into surface or groundwater consumed by residents in the surrounding community.

The Mango extracts exerted high in vitro antimicrobial activity against Salmonella spp and $P$. aeruginosa isolates, with inhibition zone diameters of $15 \mathrm{~mm}$ and $12.5 \mathrm{~mm}$ for the leaf extract, and $12 \mathrm{~mm}$ and $13 \mathrm{~mm}$ for the bark extracts respectively. Although, the antimicrobial activity of the standard antibiotic (tetracycline) used as control against Salmonella spp (inhibition zone diameter of $18 \mathrm{~mm}$ ) was higher than the $M$. indica leaf and bark extracts, tetracycline did not exert any antimicrobial effect on $P$. aeruginosa (inhibition zone diameter of $0 \mathrm{~mm}$ ). Plants have long been identified as very important sources of potentially useful bioactive principles for the development of new chemotherapeutic agents (18). The FTIR analysis of the Mango leaf and bark extracts in this study showed high presence of hydroxyl groups, phenols, alkanes, aromatic amines, carboxylic acids, esters, and ether compounds. Rajiv et al., (19) reported the presence of phenols, alkanes, aromatic amines, carboxylic acids, esters and ethers when an FT-IR spectrum analysis was conducted on methanolic extracts of Myristica dactyloids fruits.

Previous studies on Mango leaf extracts have been reported by many workers to show the presence of active functional groups such as xanthones (mangiferin), flavonols (quercertin), benzophenones and terpenoids (20). The presence of these compounds in Mango stem bark and leaf may have contributed to the antimicrobial activity of the extracts against the bacteria isolates in our study. The implication of this relatively abundant composition of active principles within the Mango leaf and bark extracts confirms their wide application in local treatment of infectious diseases.

The physico-chemical parameters of the wastewater samples indicated that the $\mathrm{pH}$ values obtained (6.5-8.0) favored the growth of the bacteria, which grew well within this $\mathrm{pH}$ range. The sulphate and phosphate contents of the wastewater samples in this study were well within permissible range when compared with maximum recommended levels of the sulphate and phosphate index values in domestic drinking water $(21,22,23)$. This fact notwithstanding, it is emphasized that release of nontreated domestic wastewater directly into water bodies will cause nutrient enrichment of such waters, which may lead to eutrophication, that results in ecosystem imbalance through disruption of natural food chain and web relationships and other adverse environmental reactions.

Plants are generally known to contain several phytochemicals such as alkaloids, flavonoids, saponins, tannins and other phenolic compounds that have antimicrobial activities (24). Phytochemical screening of Mango leaf and bark extracts have shown the presence of important phytochemical constituents such as tannins, alkaloids, saponins, cardiac glycosides, flavonoids, phenols, proteins and phytosterols. In our study, alkaloids, tannins, saponins, and cardiac glycosides were present in the extracts, while phytosterols and flavonoids were absent in the aqueous and the ethanolic extracts of the Mango leaf. Variation in phytochemical components of the various extracts may result from differences in the chemistry of the extracting solvents, which may selectively affect extraction of various bio-active metabolites.

The natural tendency of saponins to wall off microbes makes them good candidates for treating bacterial, fungal and yeast infections, boost effectiveness of certain vaccines, and destroy some types of tumors, particularly lung and blood cancers. Therefore, the presence of saponins in the leaf and bark extracts of $M$. indica, as found in our study, indicates their bioactivity against bacterial pathogens in wastewaters. The phytochemical analysis in this study confirmed the presence of active functional components in the leaf and bark extracts of $M$. indica which be responsible for the antibacterial properties of the plant materials. A potential promising candidate therefore for biological water treatment and other environmentally remediated functions would be the Mango stem bark and leaf plant parts.

\section{Conclusion:}

In conclusion, the results of this study indicated the presence of potentially pathogenic Gram-negative bacteria in wastewater. These bacteria could pose serious health risks 
to man and aquatic habitats thereby killing economically important aquatic lives. The physico-chemical parameters of the wastewater samples used in this study underscores the importance of treating wastewater adequately before release into natural water bodies, to prevent adverse environmental reactions. The release of untreated wastewater directly into water bodies may lead to eutrophication, which is the nutrient enrichment of these water bodies that negatively impacts aquatic life and may lead to ecosystem imbalance, and disruption of natural food chain and web relationships in such environments.

The phytochemical screening of the leaf and bark extracts confirmed Mango as a potential source of antibacterial agents and purifying agents for green and ecofriendly water treatment technology development that can reduce microbial loads in wastewaters to acceptable levels without causing harm to the environment from contaminated effluents.

\section{References:}

1. Akpor O. B., and Muchie, M. Environmental and public health implications of wastewater quality. Afr J Biotech. 2011; 10 (13): 2379 - 2387

2. Prescott, L. M., Harley, J. P., and Klein, D. A. Microbiology. 6th Edition, McGraw Hill, London. 2005.

3. Ammar, A., Naoufal, L., Azam, B., Dennis, D. W., and David, A. L. Phytochemicals: Extraction, isolation, and identification of bioactive compounds from plant extracts. Plants. 2017; 42 (6): 1- 23

4. Viji, M., Sathiya, M., and Murugesan, S. Phytochemical analysis and antibacterial activity of medicinal plant Cardiospermum helicacabum linn. Pharmacology Online. 2010; 2: 445-456

5. Kabuki, T., Hakajima, H., Arai M., et al. Characterization of novel antimicrobial compounds from Mango (Mangifera indica) kernel seeds. Food Chemistry. 2000; 71: 61-66

6. Abdul H., Samra A., Tahir N., et al. Antibacterial effect of mango (Mangifera indica Linn.) leaf extract against antibiotic sensitive and multi-drug resistant Salmonella typhi Pak J Pharm Sci. 2013; 26 (4): 715-719

7. Disegha, G. C., and Akani, N. P. Antifungal activity of Mangifera indica leaf extracts on selected fungi. Sci Technol. 2017; 4 (2): $136-148$

8. Orpin, J. B., Yusuf, Z., Mzungu I., and Orpin, C. A. Investigation of microorganisms associated with the spoilage of onions around Dutsinma metropolis
MOJ Biol Med. 2017; 2 (4): 00057

9. Prabhavathi, R. M., Prasad, M. P., Jayaramu, M., et al. Studies on qualitative and quantitative phytochemical analysis of Cissus quandrangularis. Adv Appl Sci Res. 2016; 7(4): 11-17

10. Ademoroti, C. M. A. Standard methods for Water and Effluent Analysis, March Prints and Consultancy, First edition. 1996; 23-28

11. Fawole, M. A., and Oso, B. A. Laboratory Manual of Microbiology. Revised Edn. Spectrum Books. Ibadan, 2001.

12. Brenner, D. J., Garity, M. G., Krieg, N. R., et al. Bergey's Manual of Systematic Bacteriology, 2005.

13. Cheesebrough, M. Biochemical tests to identify bacteria. In: Laboratory practice in tropical countries. Cheesebrough $M$ (ed.) Cambridge Edition, 2002: $63-87$

14. Bauer, A. W., Kirby, W. M., Sherris, J. C., and Turck, M. Antibiotic susceptibility testing by a standardized disk method. Am. J Clin Pathol. $1966 ; 45: 439-496$

15. Adeeyo, O. A., Odiyo, J., and Odelade, K. Chemical profiling and antimicrobial properties of phytoactive extracts from Terminalia glaucescens stem against water microbial contaminants. Open Biotechnol J. 2018; 12: 1-15

16. Ghai, S., Goel, S., Hiteshi, M., Saima, K., and Surabhi, V. Antibacterial activity of fruit peels against bacterial isolates. Global J Bio-Sci Biotech. 2018; 7(4): 570-574

17. Shivani, G., Shruti, G., Hiteshi, M., Saima, K., and Surabhi, V. Antibacterial activity of fruit peels against bacterial isolates. Glob J Biosci Biotechnol. 2018; 7 (4): 570-574

18. Muthukumaran, P., Suresh, K. K., and Karthikeyen, R. Phytochemical Screening, GC-MS, FT-IR Analysis of Methanolic Extract of Curcuma caesia Roxb. (Black Turmeric). Pharmacogn J. 2017; 9 (6): 952-956

19. Rajiv, P., Deepa, A., Vanathi, P., and Vidhya, D. Screening for Phytochemicals and FTIR analysis of Myristica dactyloids fruit extracts. Int J Pharm Pharmaceut Sci. 2017; 9 (1): 315 - 318

20. Laulloo, S. J., Bhowon, M. G., Soyfoo, S., and Chua, L.S. Nutritional and Biological evaluation of leaves of Mangifera indica from Mauritius. J Chem. 2018; 9: 1 - 9 .

21. World Health Organization (WHO). Guidelines for drinking water quality. $4^{\text {th }}$ Ed. 2011: $7853-7859$

22. Nigeria Standard for Drinking Water Quality (NSDWQ). 2015: NIS 554, 1 - 28

23. Chinwendu, E., Bright, N., Jecinta, O., and Chimaobi, K. I. Water Quality Index for the Assessment of Selected Borehole Quality in Rivers State. Euro J Environ Earth Sci. 2020; 1 (6):1 - 4

24. Mboto, C. I., Eja, M. E., Adegoke, A. A., et al. Phytochemical properties and antimicrobial activities of combined effect of extracts of the leaves of Garcinia kola, Vernonia amygdalina and honey on some medically important microorganisms. Afr. J. Microbiol Res. 2009; 3: 557-559 